\title{
Contribution of anti-inflammatory and anti- virulence effects of azithromycin in the treatment of experimental Staphylococcus aureus keratitis
}

Kana Ikemoto*, Shinya Kobayashi, Yu Haranosono, Seiko Kozai, Tomoyuki Wada, Hideki Tokushige and Akio Kawamura

\begin{abstract}
Background: We aimed to demonstrate the contribution of anti-inflammatory and anti-virulence effects of azithromycin (AZM) in ocular surface infection treatment.

Methods: Staphylococcus aureus was injected into the corneal stroma of rabbits to induce keratitis. AZM at concentrations of $0.01,0.1$, and $1 \%$ was instilled into the eye twice daily. The eyes were examined using a slit lamp and scored. The viable bacteria in the cornea were counted at $48 \mathrm{~h}$ post infection. To evaluate the antiinflammatory efficacy of AZM, S. aureus culture supernatant-induced anterior ocular inflammation in rabbit was examined using a slit lamp and scored. To evaluate the inhibitory effect of AZM on bacterial toxin production, S. aureus was cultured with AZM and hemolytic reaction in the culture supernatant was determined.

Results: In the bacterial keratitis model, AZM dose-dependently inhibited the increase in the clinical score. The viable bacterial count in the cornea treated with 1\% AZM significantly decreased compared with that of the vehicle, whereas bacterial count in 0.01 and $0.1 \%$ AZM-treated corneas was similar to that of the vehicle. In the anterior ocular inflammation model, 0.1 and 1\% AZM inhibited the increase in the clinical score. AZM inhibited hemolytic reaction at concentrations that did not inhibit bacterial growth.

Conclusions: The results demonstrated that AZM has not only anti-bacterial, but also anti-inflammatory effects, and inhibits bacterial toxin production leading to ocular surface damage in bacterial infection. Thus, the therapeutic effect of AZM against ocular infections is expected to be higher than that which could be assumed if it only had anti-bacterial activity.
\end{abstract}

Keywords: Anti-inflammatory, Anti-virulence, Azithromycin, Keratitis, Staphylococcus aureus, Ocular infection

* Correspondence: k-kurita@senju.co.jp

Senju Pharmaceutical Co., Ltd., 6-4-3 Minatojima-Minamimachi, Chuo-Ku,

Kobe, Hyogo 650-0047, Japan

(c) The Author(s). 2020 Open Access This article is licensed under a Creative Commons Attribution 4.0 International License, which permits use, sharing, adaptation, distribution and reproduction in any medium or format, as long as you give appropriate credit to the original author(s) and the source, provide a link to the Creative Commons licence, and indicate if changes were made. The images or other third party material in this article are included in the article's Creative Commons licence, unless indicated otherwise in a credit line to the material. If material is not included in the article's Creative Commons licence and your intended use is not permitted by statutory regulation or exceeds the permitted use, you will need to obtain permission directly from the copyright holder. To view a copy of this licence, visit http://creativecommons.org/licenses/by/4.0/ The Creative Commons Public Domain Dedication waiver (http://creativecommons.org/publicdomain/zero/1.0/) applies to the data made available in this article, unless otherwise stated in a credit line to the data. 


\section{Background}

After bacterial invasion, the initial acute inflammatory response against the bacteria is initiated by the innate immune system of the body to eliminate the pathogen and further stimulate adaptive immune responses [1]. Although these processes are important to eradicate the invading pathogens, they have the risk of simultaneously damaging the host tissues. Furthermore, the ability of bacteria to cause diseases is associated with virulence factors such as leukocidal and hemolytic toxins, which are known to induce inflammation [2, 3]. Ocular infectious diseases can cause scarring due to the inflammatory response as describe above, which may not be easily resolved, and ultimately result in blindness or visual impairments [4]. This encourages the use of broad-spectrum bactericidal agents for the treatment of ocular infections without identifying causative pathogens or without testing their susceptibility to anti-microbial agents. Antivirulence therapy, which is independent of bacterial growth, can be a potential treatment option for ocular infection. Several studies have demonstrated that inhibition of bacterial toxin production could suppress ocular tissue damage $[5,6]$.

Azithromycin (AZM) is a broad-spectrum antibiotic that has been shown to be effective against grampositive, gram-negative, and atypical bacteria. It is widely used in clinical practice. It has been recognized that AZM exerts not only anti-bacterial activity but also anti-inflammatory effects, which are related to the NF- $\mathrm{KB}$ pathway [7-10], inhibition of quorum sensing, and anti-virulence effects [11-14]. The antiinflammatory effect of AZM in the ocular surface has been demonstrated in lipopolysaccharide-induced rats and in corneal epithelial cells stimulated with zymosan $[9,15]$. These studies have shown that AZM suppresses the signs of inflammation and reduces the level of several proinflammatory factors. Although the anti-virulence effect of AZM on gram-positive bacteria which are the major causatives of ocular infection is poorly known, it is well known that AZM suppresses the production of bacterial virulence factor and formation of biofilm via inhibition of quorum sensing in Pseudomonas aeruginosa [11, 12]. These studies provide evidence of other effects besides the conventional anti-bacterial effect of AZM, but it is unclear whether anti-inflammatory and anti-virulence effects of AZM can contribute to the treatment of ocular infection.

In this study, we investigated whether AZM exerts anti-inflammatory and anti-virulence effects in addition to anti-bacterial activity in a staphylococcal keratitis model in order to elucidate their contribution in the treatment of ocular infection.

\section{Methods}

\section{Reagents}

Azithromycin at concentrations of $0.01,0.1$, and $1 \%$ along with its vehicle was prepared for this study by Senju Pharmaceutical Co., Ltd. (Osaka, Japan). These formulations all contained DuraSite, which is a proprietary polymeric mucoadhesive delivery system, prepared by Senju Pharmaceutical Co., Ltd. An ophthalmic corticosteroid, betamethasone sodium phosphate $0.1 \%$ (Rinderon $^{\circ}$ ophthalmic, otic, and nasal solution $0.1 \%$ ), was purchased from Shionogi \& Co., Ltd. (Osaka, Japan). Saline (Otsuka normal saline) was purchased from Otsuka Pharmaceutical Factory, Inc. (Tokushima, Japan).

Ten milligrams of azithromycin dihydrate, which was purchased from Tokyo Chemical Industry Co., Ltd. (Tokyo, Japan) for in vitro assays, was dissolved in $1 \mathrm{~mL}$ of ethanol. That solution was then filtered and diluted with bacterial growth medium. Preserved rabbit blood was purchased from Kojin Bio Co., Ltd. (Tokyo, Japan).

\section{Animals}

Seventy-three male Japanese white rabbits weighing 1.3-1.9 $\mathrm{kg}$ were supplied by Kitayama Labes Co., Ltd. (Nagano, Japan). All procedures were performed in accordance with the statement of the Association for Research in Vision and Ophthalmology and the guidelines for animal experimentation of Senju Pharmaceutical Co., Ltd., and the protocol was approved by the Institutional Animal Care and Use Committee (approval nos. 20,140,903-01, and 20,160,310-01).

\section{Bacterial strain}

Staphylococcus aureus ATCC 25923 supplied by the American Type Culture Collection (Manassas, VA) was used in this study. The minimal inhibitory concentrations of AZM was reported to be $2 \mu \mathrm{g} / \mathrm{mL}$ for this strain, and it was defined as AZM-susceptible based on the Clinical Laboratory Standards Institute breakpoint (M100-S18) [16]. Furthermore, it has been reported that this strain can induce keratitis in rabbits $[17,18]$. Staphylococcus aureus was grown at $32{ }^{\circ} \mathrm{C}$ on soybean casein digest (SCD) agar (Nihon Pharmaceutical Co., Ltd., Tokyo, Japan) or tryptic soy broth (TSB) (Becton, Dickinson and Company, Franklin Lakes, NJ).

\section{S. aureus keratitis rabbit model}

Forty-one rabbits were anesthetized by intramuscular injection of a 3:1 mixture of $50 \mathrm{mg} / \mathrm{mL}$ ketamine (Ketalar for intramuscular injection $500 \mathrm{mg}$; Daiichi-Sankyo Propharma Co., Ltd., Tokyo, Japan) and $20 \mathrm{mg} / \mathrm{mL}$ xylazine (Celactar ${ }^{\circ}$ \% injection; Bayer Yakuhin, Ltd., Tokyo, Japan). Staphylococcus aureus cells were suspended with saline. The viable bacteria were quantified using the agar dilution plate method $\left(4.7 \times 10^{6}\right.$ colony-forming units (CFU) per milliliter). A $30 \mu \mathrm{L}$ of bacterial suspension was injected into the corneal stroma of right eye. The left eye 
was not used for throughout the experiment. To avoid that the shortage of the number of viable bacteria limited the assessable dose-response range, the number was set higher than those of the previous reports. Oxybuprocaine hydrochloride ophthalmic solution (Benoxil ${ }^{\circ}$ ophthalmic solution 0.4\%; Santen Pharmaceutical Co., Ltd., Osaka, Japan) was topically applied prior to inoculation. Slit-lamp examination (SLE) was performed at 5, 12, 24, 36, and $48 \mathrm{~h}$ after inoculation, and the clinical severity of ocular discharge, hypopyon, and infection signs in the cornea, conjunctiva, nictitating membrane, and iris were scored according to a previously reported standard scale of ocular infection [19]. A masked observer performed all SLE scoring. Eleven rabbits were excluded due to leakage of inoculated suspension from corneal stroma immediately after administration. Thirty rabbits that were successfully inoculation were selected and randomly divided into four groups $(n=7-8)$. Azithromycin at concentrations of $0.01,0.1$, and $1 \%$ or its vehicle was instilled into the right eye $(50 \mu \mathrm{L} /$ eye, twice daily for 2 days). The topical treatment was started $5 \mathrm{~h}$ post inoculation when animals presented sign of ocular infection. The rabbits were euthanized by an intravenous overdose of sodium pentobarbital after SLE at $48 \mathrm{~h}$. The corneas were removed, finely minced, serially diluted with sterile saline, and plated onto mannitol salt agar plates for quantification of viable bacteria in the cornea.

\section{Bacterial culture supernatant-induced anterior ocular inflammation rabbit model}

Bacterial cells were grown overnight in TSB, centrifuged, and passed through a $0.22-\mu \mathrm{m}$ filter to obtain bacterium-free $S$. aureus supernatant (SaS). Thirty-two rabbits were randomly divided into four groups. In total, $50 \mu \mathrm{L}$ of $\mathrm{SaS}$ was instilled into the rabbit's right eye three times at $10 \mathrm{~min}$ intervals to induce anterior ocular inflammation. Physiological saline or AZM at concentrations of 0.1 and $1 \%$ was instilled at $2 \mathrm{~h}$ before and at $5 \mathrm{~h}$ after the first challenge $(50 \mu \mathrm{L} /$ eye, twice daily). Betamethasone sodium phosphate $0.1 \%$, was instilled into the eye for 2 days from the day before the induction of inflammation $(50 \mu \mathrm{L} /$ eye, 4 times daily). This ophthalmic corticosteroid was used as a positive control to elucidate the effectiveness of anti-inflammatory treatment in our model. SLE was performed at $3,6,12$, and $24 \mathrm{~h}$ after the first challenge, and the severity was scored according to the criteria used for the keratitis model.

\section{Assay of hemolytic reaction}

Bacterial cells were grown in TSB with or without (control group) AZM at concentrations of $0.008-8 \mu \mathrm{g} / \mathrm{mL}$ for approximately $16 \mathrm{~h}$ under agitation. After measuring the optical density at $660 \mathrm{~nm}$ to evaluate the growth of bacterial cells in the culture solution, bacterial culture supernatant was collected by centrifugation at $1610 \times g$ for $2 \mathrm{~min}$ and the residual bacterial cells were removed using a $0.22-\mu \mathrm{m}$ filter. The bacterial supernatant was incubated with equal volume of $1 \%$ rabbit red blood cells suspended in saline for $10 \mathrm{~min}$ at $37^{\circ} \mathrm{C}$. The reaction mixture was centrifuged at $1000 \times g$ for $10 \mathrm{~min}$ to remove the intact red blood cells, and the supernatant was transferred into a 96-well microplate. Hemolysis was detected by measuring the absorbance at $440 \mathrm{~nm}$ as an indicator of hemoglobin release into the supernatant. The absorbance of the control group was defined as $100 \%$ and the bacterial number and the hemolysis rate of each group were calculated.

\section{Statistics}

Differences in the SLE scores and CFU per cornea in the bacterial keratitis model between the AZM-treated and vehicle groups were compared using the one-sided Shirley-Williams test and one-sided Williams test, respectively. Differences in the SLE scores in SaS-induced anterior ocular inflammation model between each drug group and saline group were compared at each time point using the one-sided Steel test. Differences in the rate of hemolysis and bacterial number in the in vitro assay between the AZM-contained and control groups were compared using the one-sided Williams test. The results with a $p$ value of $<0.05$ were considered statistically significant. Data were processed and analyzed using Microsoft Excel 2010 (Microsoft Corp.) and Ekuseru-Toukei 2012 (Social Survey Research Information Co., Ltd.).

\section{Results}

\section{Effect of AZM on bacterial keratitis model}

Inoculation of $S$. aureus into the corneal stroma in rabbits induced clinical signs mainly in the cornea, conjunctiva, nictitating membrane, and iris. In the vehicle group, the SLE score was increased at $5 \mathrm{~h}$ after inoculation and reached the maximum at $36 \mathrm{~h}$ after inoculation (Fig. 1, Table 1). Azithromycin decreased the SLE scores in a

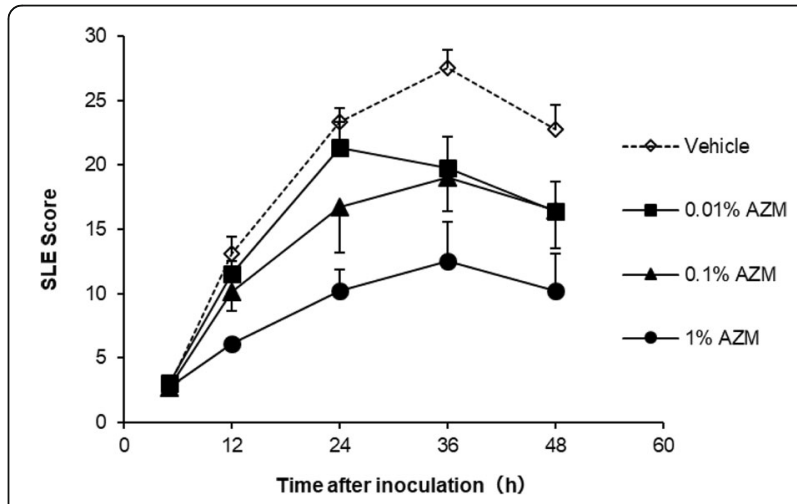

Fig. 1 Effect of $0.01,0.1$, and 1\% azithromycin in the rabbit bacterial keratitis model induced by intrastromal injection of $1.41 \times 10^{5} \mathrm{CFU}$ of S. aureus. The data represent the mean and standard error $(n=7-8)$ 
Table 1 Median of slit lamp examination score in the rabbit bacterial keratitis model

\begin{tabular}{|c|c|c|c|c|c|c|c|}
\hline \multirow[t]{3}{*}{ Treatment } & & \multirow[t]{3}{*}{$\mathrm{n}$} & \multicolumn{5}{|c|}{ Median (1st quartile - 3rd quartile) } \\
\hline & & & \multicolumn{5}{|c|}{ Time after inoculation } \\
\hline & & & $5 \mathrm{~h}$ & $12 \mathrm{~h}$ & $24 \mathrm{~h}$ & $36 \mathrm{~h}$ & $48 \mathrm{~h}$ \\
\hline Vehicle & & 7 & $2.50(2.25-2.75)$ & $13.00(11.00-15.00)$ & $23.00(21.25-25.00)$ & $29.00(25.50-29.75)$ & $25.50(18.50-25.75)$ \\
\hline \multirow[t]{3}{*}{ Azithromycin } & $0.01 \%$ & 8 & $3.50(2.63-4.00)$ & $12.25(9.38-13.25)$ & $21.50(18.75-25.00)$ & $21.00 *(15.75-24.63)$ & $18.25(15.88-19.88)$ \\
\hline & $0.1 \%$ & 7 & $3.00(2.00-3.00)$ & $11.00(7.50-13.00)$ & $21.50(8.25-23.25)$ & $21.50 *(13.00-24.50)$ & $22.00(10.25-22.75)$ \\
\hline & $1 \%$ & 8 & $2.25(2.00-3.50)$ & $6.00 *(5.50-6.50)$ & $10.25 *(7.75-12.88)$ & $11.75 *(6.88-16.63)$ & $9.50 *(6.38-12.00)$ \\
\hline
\end{tabular}

${ }^{*} p<0.05$ compared with the vehicle (Shirley-Williams test, one-sided)

dose-dependent manner. The SLE score in the 0.01 and $0.1 \%$ AZM groups reached the maximum at 24 and $36 \mathrm{~h}$, respectively, and they were significantly lower than that of the vehicle group at $36 \mathrm{~h}$ after inoculation $(p<0.05$; Table 1). The SLE score of the $1 \%$ AZM group reached the maximum at $36 \mathrm{~h}$ after inoculation, and the scores were significantly lower than those of the vehicle group from 12 to $48 \mathrm{~h}$ after inoculation. Treatment with $1 \%$ AZM significantly decreased the number of viable bacteria per cornea compared with that of the vehicle $(p<0.05)$, although the numbers of viable bacteria per cornea in the 0.01 and $0.1 \%$ AZM groups were similar to that of the vehicle group (Table 2).

\section{Effect of AZM on anterior ocular inflammation}

Administration of $\mathrm{SaS}$ induced the clinical signs hyperemia and edema in the conjunctiva, redness and edema in the nictitating membrane, hyperemia in the iris, and ocular discharge (Fig. 2). In the saline group, the SLE score was increased at $3 \mathrm{~h}$ after induction and reached the maximum at $12 \mathrm{~h}$ after induction (Fig. 3, Table 3). The SLE scores of the AZM groups were lower than those of the saline group, and treatment with 1\% AZM significantly reduced the SLE score at $12 \mathrm{~h}(p=0.0113)$. The SLE score of the $0.1 \%$ betamethasone sodium phosphate group was significantly lower than that of the saline group at 6 and $12 \mathrm{~h}$ ( $p=0.0085$ and 0.0037 , respectively). The SLE score of the $1 \%$ AZM group at $12 \mathrm{~h}$ was similar to that of the $0.1 \%$ betamethasone sodium phosphate group.

Table 2 Number of viable bacteria per cornea at $48 \mathrm{~h}$ postinoculation

\begin{tabular}{llll}
\hline Treatment & $n$ & $\begin{array}{l}\text { Mean } \pm \text { S.E.M } \\
\left(\log _{10} \text { CFU/cornea }\right)\end{array}$ \\
\hline Vehicle & & 7 & $3.64 \pm 0.51$ \\
Azithromycin & $0.01 \%$ & 8 & $3.12 \pm 0.41$ \\
& $0.1 \%$ & 7 & $3.70 \pm 0.46$ \\
& $1 \%$ & 8 & $2.12 \pm 0.29 *$ \\
\hline
\end{tabular}

The detection limit was $1.30 \log _{10}$ CFU/cornea

${ }^{*} p<0.05$ compared with the vehicle (Williams test, one-sided)

\section{Hemolytic reaction and secretion proteins in the bacterial supernatant}

Bacterial growth was significantly inhibited by AZM at or above $0.5 \mu \mathrm{g} / \mathrm{mL}$ concentration (Fig. 4). Hemolytic activity was significantly inhibited by AZM at or above $0.125 \mu \mathrm{g} / \mathrm{mL}$ concentration.

\section{Discussion}

The objective of this study was to clarify whether the anti-inflammatory and anti-virulence effects of AZM contributed to its therapeutic effects against ocular infection. It is well known that macrolide exerts antiinflammatory effects on the host, which was first reported by long-term treatment of respiratory diseases with erythromycin [20]. Although there are few reports of such effects in ophthalmology, the inhibitory effect of AZM on the production of proinflammatory cytokines has been demonstrated in human corneal epithelial cells [9]. Furthermore, it has been reported that the clinical signs in the conjunctiva were suppressed by topical application of AZM in acute anterior ocular inflammation models [15, 21]. However, the contribution of antiinflammatory effects of AZM in the treatment of ocular infection has not been fully elucidated.

In the bacterial keratitis model of the present study, 1\% AZM suppressed the clinical signs of ocular infection and inhibited bacterial growth in the cornea. On the other hand, 0.01 and $0.1 \%$ AZM suppressed the clinical signs but did not inhibit bacterial growth in the cornea. These data suggest the involvement of effects other than the anti-bacterial activity in the therapeutic effects of AZM against ocular infectious diseases. To elucidate these effects of AZM in a bacterial keratitis model, in the present study, we developed an SaS-induced anterior ocular inflammation rabbit model that represents the inflammation of ocular infections under bacteria-free conditions. Staphylococcus aureus-derived secretions including toxins mediate the destruction of ocular tissue and contribute to the induction of an inflammatory response [22-24]. Hemolytic toxin, such as alpha-toxin and Panton-Valentine toxin are thought to contribute to pathogenesis of ocular infection $[5,25,26]$. This kind of bacterial pore-forming toxins induces host cell lysis 


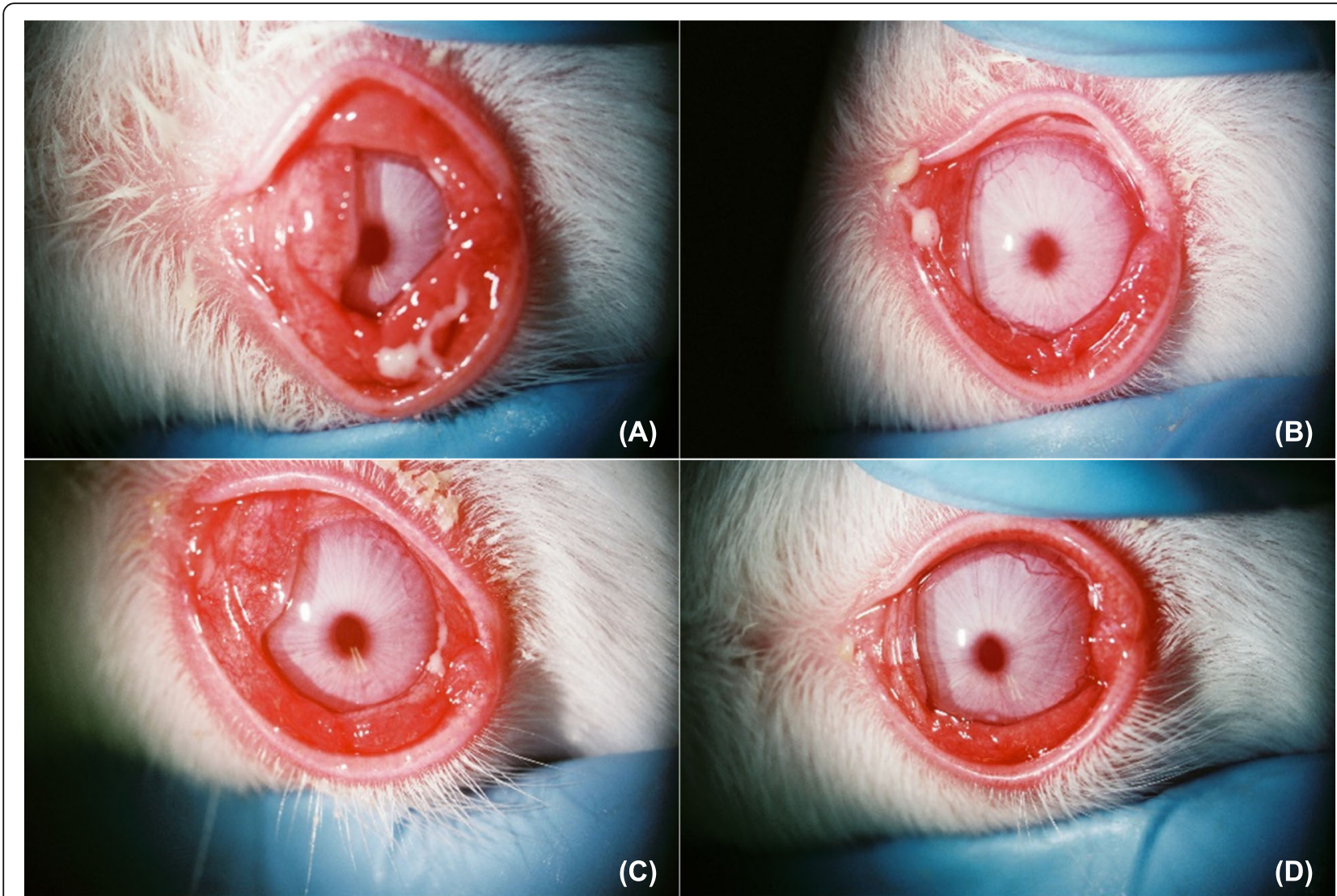

Fig. 2 Bacteria culture supernatant induced anterior ocular inflammation in rabbits $12 \mathrm{~h}$ post induction. Conjunctival hyperemia and edema, nictitating membrane redness and edema, iris hyperemia, and ocular discharge were observed in the saline- (a), $0.1 \%$ betamethasone sodium phosphate- (b), and 0.1 and 1\% azithromycin-treated eyes (c, d)

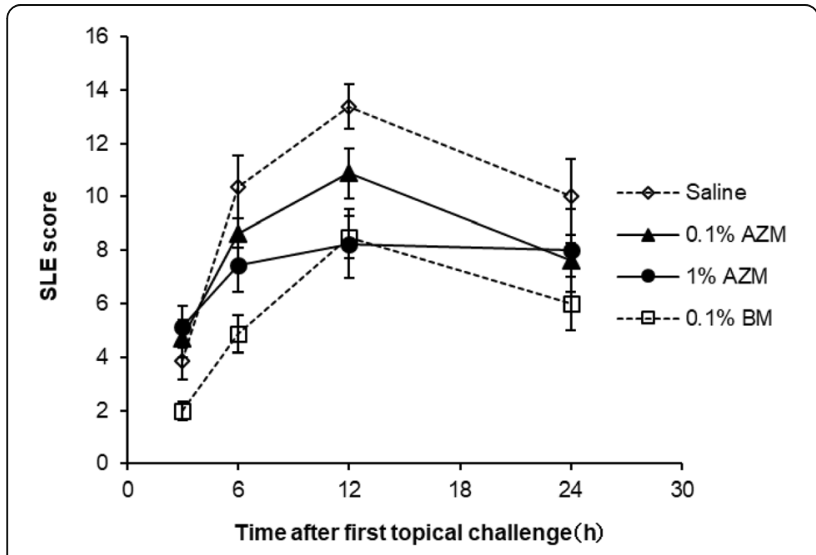

Fig. 3 Effect of $0.1 \%$ azithromycin and $0.1 \%$ betamethasone sodium phosphate on aseptic anterior ocular inflammation induced by topical challenge with bacterial culture supernatant in rabbit eyes. The data represent the mean and standard error $(n=8)$ leading to destruction of corneal tissues in the infected eye. Instillation of SaS containing bacterial toxins, with confirmed hemolytic activity, caused inflammation in the anterior ocular surface. Therefore, our model partially represents the inflammation caused by ocular surface infection. In this model, 0.1 and 1\% AZM suppressed the clinical signs under the same frequency of application as that in the rabbit bacterial keratitis model. These results reveal that AZM suppresses the clinical signs of ocular infection induced by bacterial virulence, and the mechanism is independent of the anti-bacterial effect. Conjunctival homogenate myeloperoxidase activity was examined in order to further confirm anti-inflammatory effects of AZM in this model, but that was undetectable in all groups (data not shown).

It is known that AZM at sub-minimal inhibitory concentration inhibits the production of bacterial virulence factor and formation of biofilm [11-14]. Bacterial secretion is one of the main causes of inflammation in the ocular surface, indicating that inhibiting the production of bacterial virulence factor could be effective in the treatment of ocular infection. Azithromycin decreased the hemolytic activity of $S$. aureus at a concentration 
Table 3 Median of Slit lamp examination score in the rabbit anterior ocular inflammation model

\begin{tabular}{|c|c|c|c|c|c|c|}
\hline \multirow[t]{3}{*}{ Treatment } & & \multirow[t]{3}{*}{$\mathrm{n}$} & \multicolumn{4}{|c|}{ Median (1st quartile - 3rd quartile) } \\
\hline & & & \multicolumn{4}{|c|}{ Time after first topical challenge } \\
\hline & & & $3 \mathrm{~h}$ & $6 \mathrm{~h}$ & $12 \mathrm{~h}$ & $24 \mathrm{~h}$ \\
\hline Saline & & 8 & $4.00(2.25-5.13)$ & $12.00(8.38-12.25)$ & $14.00(12.00-14.25)$ & $9.75(7.25-12.25)$ \\
\hline \multirow[t]{2}{*}{ Azithromycin } & $0.1 \%$ & 8 & $4.25(3.50-5.63)$ & $8.00(7.50-9.00)$ & $11.50(9.75-12.38)$ & $8.00(7.50-8.63)$ \\
\hline & $1 \%$ & 8 & $5.25(4.00-6.25)$ & $6.50(5.38-10.25)$ & $8.25 *(5.25-11.25)$ & $7.75(4.63-11.50)$ \\
\hline $\begin{array}{l}\text { Betamethasone } \\
\text { phosphate ester }\end{array}$ & $0.1 \%$ & 8 & $2.00(1.50-2.13)$ & $5.25 * *(3.63-6.00)$ & $8.75 * *(7.88-9.63)$ & $6.00(4.63-8.25)$ \\
\hline
\end{tabular}

${ }^{*} p<0.05$ and ${ }^{* *} p<0.01$ compared with the saline (Steel test, one-sided)

that did not inhibit their growth. This result is associated with the therapeutic effect of AZM at the concentration of $0.1 \%$ or less in the rabbit bacterial keratitis model. .

There are some possible limitations to this study. First, because it was difficult to distinguish between the antibacterial effects and other effects of 1\% AZM, we could not fully elucidate the extent to which those other effects contributed to the treatment of ocular infections. It may be possible to clarify this by comparing the treatment effects of appropriate anti-bacterial agents that only possess an anti-bacterial effect (without anti-inflammatory effect and anti-virulence effect) with that of 1\% AZM on ocular infection. Furthermore, the effects of AZM on azithromycin-resistant bacteria may reveal the action of anti-inflammatory and anti-virulence effects. Secondly, although we tried to detect the bacterial toxins in the culture supernatant that were reduced by AZM using an immunoassay (data not shown), we could not identify

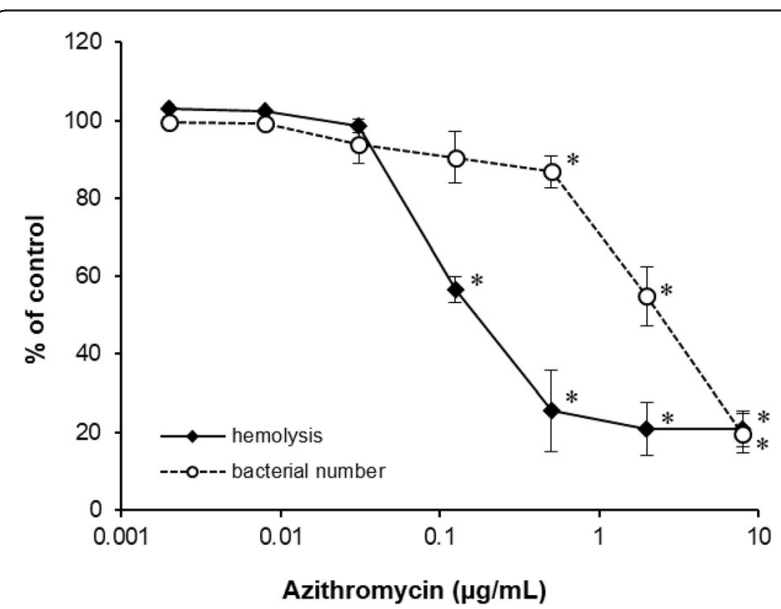

Fig. 4 Inhibitory effect of azithromycin on production of bacterial virulence factor and bacterial growth. Experiments were performed in duplicate. Bacterial cells were grown in broth medium with increasing doses of azithromycin for $16 \mathrm{~h}$. Rate of bacterial number density and hemolytic activity to control groups are shown. The data represent the mean and standard error $(n=3)$. The significance of differences compared with the control group is designated as ${ }^{*} p<0.05$ (Williams test, one-sided) these toxins. It is considered that AZM can suppress the production of pore-forming toxins, such as alpha-toxin and Panton-Valentine leucocidin, which are major virulence factors leading to corneal damage by $S$. aureus [5, 25-27]. The inhibition of bacterial virulence factors by AZM was not confirmed in vivo because the bacterial virulence factor influenced by AZM had not been identified in the in vitro study. It remains uncertain how the anti-virulence effect of AZM, which was shown to be independent of its anti-bacterial effect in this study, contributed to the treatment of ocular infections in vivo. Further studies are needed to understand the specific anti-virulence mechanism of AZM. Such studies can expand our understanding of the effects of AZM beyond that of its anti-bacterial effect and might provide new therapeutic strategies to prevent the emergence of resistant bacteria for ocular infections.

\section{Conclusions}

The present study demonstrated that AZM exerts not only anti-bacterial activity but also anti-inflammatory effects on the host and inhibits the production of bacterial virulence factor. The results also elucidated that nonantibacterial effects contributed to the therapeutic effect of AZM against ocular infection. These effects of AZM potentially suppress ocular tissue damage from excessive inflammatory response, and consequently the therapeutic effect of AZM against ocular infection may be higher than that predicted from the in vitro antibacterial activity.

\section{Abbreviations}

AZM: Azithromycin; CFU: colony-forming units; SaS: Staphylococcus aureus supernatant; SCD: soybean casein digest; SLE: Slit-lamp examination;

TSB: tryptic soy broth

\section{Acknowledgements}

Not applicable

\section{Authors' contributions}

$\mathrm{Kl}$ participated in the design, experimentation and drafted the manuscript. SK1 participated in the experimentation. SK2 and TW conceived the inflammation model induced by topical application of bacterial culture supernatant. TW and HT participated in the design, interpretation of data, and critical revision of the manuscript for important intellectual content. YH and AK participated in the critical revision the manuscript for important 
intellectual content. All authors revised the manuscript, read and approved the final manuscript.

\section{Funding}

This research receives no funding.

\section{Availability of data and materials}

The datasets used and/or analyzed during the current study are available from the corresponding author on reasonable request.

\section{Ethics approval and consent to participate}

All animal procedures were performed in accordance with the statement of the Association for Research in Vision and Ophthalmology and the guidelines for animal experimentation of Senju Pharmaceutical Co. Ltd., and the protocol was approved by the Institutional Animal Care and Use Committee (approval nos. 20140903-01, and 20160310-01).

\section{Consent for publication}

Not applicable

\section{Competing interests}

The authors declare that they have no competing interests.

Received: 18 December 2019 Accepted: 27 February 2020 Published online: 06 March 2020

\section{References}

1. Li Y, Wei C, Xu H, Jia J, Wei Z, Guo R, et al. The immunoregulation of Th17 in host against intracellular bacterial infection. Mediat Inflamm. 2018;2018: 6587296.

2. Vandenesch F, Lina G, Henry T. Staphylococcus aureus hemolysins, bicomponent leukocidins, and cytolytic peptides: a redundant arsenal of membrane-damaging virulence factors? Front Cell Infect Microbiol. 2012;2:12.

3. Dragneva Y, Anuradha CD, Valeva A, Hoffmann A, Bhakdi S, Husmann M. Subcytocidal attack by staphylococcal alpha-toxin activates NF-kappa B and induces interleukin-8 production. Infect Immun. 2001;69(4):2630-5.

4. Ubani UA. Bacteriology of external ocular infections in aba, South Eastern Nigeria. Clin Exp Optom. 2009;92(6):482-9.

5. McCormick CC, Caballero AR, Balzli CL, Tang A, O'Callaghan RJ. Chemical inhibition of alpha-toxin, a key corneal virulence factor of Staphylococcus aureus. Invest Ophthalmol Vis Sci. 2009;50(6):2848-54.

6. Suzuki T, Wada T, Kozai S, Ike Y, Gilmore MS, Ohashi Y. Contribution of secreted proteases to the pathogenesis of postoperative Enterococcus faecalis endophthalmitis. J Cataract Refract Surg. 2008;34(10):1776-84.

7. Cheung PS, Si EC, Hosseini K. Anti-inflammatory activity of azithromycin as measured by its NF-kappa B, inhibitory activity. Ocul Immunol Inflamm. 2010;18(1):32-7.

8. Aghai ZH, Kode A, Saslow JG, Nakhla T, Farhath S, Stahl GE, et al. Azithromycin suppresses activation of nuclear factor-kappa B and synthesis of pro-inflammatory cytokines in tracheal aspirate cells from premature infants. Pediatr Res. 2007;62(4):483-8.

9. Li DQ, Zhou N, Zhang L, Ma P, Pflugfelder SC. Suppressive effects of azithromycin on zymosan-induced production of proinflammatory mediators by human corneal epithelial cells. Invest Ophthalmol Vis Sci. 2010:51(11):5623-9.

10. Steel HC, Theron AJ, Cockeran R, Anderson R, Feldman C. Pathogen- and host-directed anti-inflammatory activities of macrolide antibiotics. Mediat Inflamm. 2012;2012:584262.

11. Tateda K, Comte R, Pechere JC, Köhler T, Yamaguchi K, Van Delden C. Azithromycin inhibits quorum sensing in Pseudomonas aeruginosa. Antimicrob Agents Chemother. 2001:45(6):1930-3.

12. Zeng J, Zhang N, Huang B, Cai R, Wu B, E S, et al. Mechanism of azithromycin inhibition of HSL synthesis in Pseudomonas aeruginosa. Sci Rep. 2016;6:24299.

13. Gui Z, Wang H, Ding T, Zhu W, Zhuang X, Chu W. Azithromycin reduces the production of a-hemolysin and biofilm formation in Staphylococcus aureus. Indian J Microbiol. 2014;54(1):114-7.

14. Yanagihara K, Morinaga Y, Nakamura S, Seki M, Izumikawa K, Kakeya H, et al. Subinhibitory concentrations of telithromycin, clarithromycin and azithromycin reduce methicillin-resistant Staphylococcus aureus coagulase in vitro and in vivo. J Antimicrob Chemother. 2008;61(3):647-50.
15. Fernandez-Robredo P, Recalde S, Moreno-Orduña M, García-García L, Zarranz-Ventura J, García-Layana A. Azithromycin reduces inflammation in a rat model of acute conjunctivitis. Mol Vis. 2013;19:153-65.

16. Fuentes F, Izquierdo J, Martín MM, Gomez-Lus ML, Prieto J. Postantibiotic and sub-MIC effects of azithromycin and isepamicin against Staphylococcus aureus and Escherichia coli. Antimicrob Agents Chemother. 1998;42(2):414-8.

17. Oguz H, Ozbilge H, Oguz E, Gurkan T. Effectiveness of topical taurolidine versus ciprofloxacin, ofloxacin, and fortified cefazolin in a rabbit Staphylococcus aureus keratitis model. Curr Eye Res. 2005;30(3):155-61.

18. Callegan MC, Hobden JA, Hill JM, Insler MS, O'Callaghan RJ. Topical antibiotic therapy for the treatment of experimental Staphylococcus aureus keratitis. Invest Ophthalmol Vis Sci. 1992;33(11):3017-23.

19. Wada $T$, Naka H, Tokushige $H$, Sakaki H, Ogawa $T$, Jensen $H$, et al. Treatment of rabbit corneal infections with ophthalmic gatifloxacin: a concentration dependence study. Adv Ther. 2004;21(1):1-12.

20. Kudoh S, Azuma A, Yamamoto M, Izumi T, Ando M. Improvement of survival in patients with diffuse panbronchiolitis treated with low-dose erythromycin. Am J Respir Crit Care Med. 1998;157(6 Pt 1):1829-32.

21. Sadrai Z, Hajrasouliha AR, Chauhan S, Saban DR, Dastjerdi MH, Dana R. Effect of topical azithromycin on corneal innate immune responses. Invest Ophthalmol Vis Sci. 2011;52(5):2525-31.

22. Callegan MC, Engel LS, Hill JM, O'Callaghan RJ. Corneal virulence of Staphylococcus aureus: roles of alpha-toxin and protein a in pathogenesis. Infect Immun. 1994;62(6):2478-82.

23. O'Callaghan RJ, Callegan MC, Moreau JM, Green LC, Foster TJ, Hartford OM, et al. Specific roles of alpha-toxin and beta-toxin during Staphylococcus aureus corneal infection. Infect Immun. 1997;65(5):1571-8.

24. O'Callaghan RJ. The pathogenesis of Staphylococcus aureus eye infections. Pathogens. 2018;7(1):9.

25. Lakhundi S, Siddiqui R, Khan NA. Pathogenesis of microbial keratitis. Microb Pathog. 2017;104:97-109.

26. Astley R, Miller FC, Mursalin MH, Coburn PS, Callegan MC. An eye on Staphylococcus aureus toxins: roles in ocular damage and inflammation. Toxins (Basel). 2019;11(6):356

27. Kane TL, Carothers KE, Lee SW. Virulence factor targeting of the bacterial pathogen Staphylococcus aureus for vaccine and therapeutics. Curr Drug Targets. 2018;19(2):111-27.

\section{Publisher's Note}

Springer Nature remains neutral with regard to jurisdictional claims in published maps and institutional affiliations.

Ready to submit your research? Choose BMC and benefit from:

- fast, convenient online submission

- thorough peer review by experienced researchers in your field

- rapid publication on acceptance

- support for research data, including large and complex data types

- gold Open Access which fosters wider collaboration and increased citations

- maximum visibility for your research: over $100 \mathrm{M}$ website views per year

At $\mathrm{BMC}$, research is always in progress.

Learn more biomedcentral.com/submission 